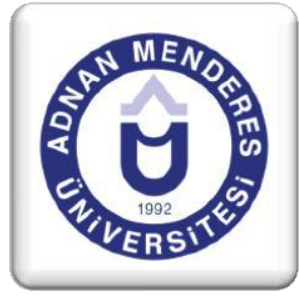

\title{
Sınıf Öğretmenlerinin Öğretimsel Performanslarının Okul Müdürleri Tarafından Değerlendirilmesi (Ankara İli Çankaya İlçesi Örneği) Tansel YAZICIOĞLU*
}

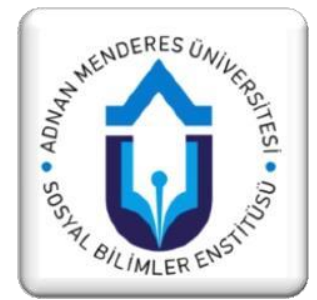

Özet

Eğitim denetiminde, öğrenme ve öğretme sürecinin geliştirilmesi için öğretmenlere yapılan yardımlar önemli görülmektedir. Öğretmenlerin potansiyellerini fark etmeleri ve etkili biçimde kullanabilmelerinde okul müdürleri önemli rol oynamaktadır. Sınıf içi performans, eğitim öğretimin en kritik noktasını oluşturmaktadır. Bu nedenle okul müdürünün sınıfa girmesi ve sinıfta neler olup bittiğini ayrıntılı olarak raporlayabilmesi son derece önemlidir. $\mathrm{Bu}$ araştırmanın amacı, ilkokul müdürlerinin sınıf içi gözlem tekniklerini kullanarak sınıf öğretmenlerinin öğretim performanslarını belirlemektir. Tarama modelinin kullanıldığ Müdürü, 60 öğretmen ve 1500 öğrenci katılmıştır. Araştırmada, gözlem yoluyla bilgi toplama yöntemi kullanılarak, hem birinci elden hem de ikinci elden gözlemler yapılmış, gözlemle veri toplamada yazılı tasvirler kullanılmıştır. Araştırma bulguları sınıf öğretmenlerinin sorularına, konuşma davranışlarına, sözel olmayan öğretmen davranışlarına, hareket ve sözel akış şemalarına ilişkin öğretimsel performanslarını ortaya koymuştur.

Keywords: Sınıf içi gözlem, öğrenme, sözel olmayan öğretmen davranışı, öğretim

\section{Evaluation of Instructional Performance of Classroom Teachers by School Principals}

\begin{abstract}
In training supervision, assistance to teachers for the development of the learning and teaching proces sseems important. School principals play an important role in recognizing teachers' potential and using them effectively. Classroom performance is the most critical point of education and training. For this reason, it is very important that the schoolmaster can report in detail what is going on in the class and what is happening in the class. The purpose of this research is to determine the teaching performances of classroom teachers using in-class observation techniques of elementary school principals. In this study, 10 school administrators, 60 teachers and 1,500 students participated in the survey. In the study, both first and second hand observations were made by using the method ofcollecting information through observation, and observations and data were used. The findings of the research reveal the instructional performances of the classroom teachers on the questions, speech behaviors, nonverbal teacher behaviors, movement and verbal flowcharts.
\end{abstract}

Keywords: Classroom observation, learning, nonverbal teacher behavior, teaching

*Dr. Öğretim Üyesi, Nevşehir Hacı Bektaş Veli Üniversitesi, tanselyazicioglu@ nevsehir.edu.tr 


\section{Giriş}

Eğitimin geliştirilmesinde çok büyük bir öneme sahip olan denetime ve denetim uygulamalarına sürekli olarak yeni bakış açıları getirilmektedir. Eğitim ile ilgili diğer alanlarda olduğu gibi denetim alanında yaşanan gelişmeler de çağın gereklerine ve yeni okul anlayışına göre şekillenmektedir. Çağdaş denetim yaklaşımları sınıf içi etkinliklerinin geliştirilerek, etkililik düzeyinin en üst seviyeye çıkarılması üzerinde yoğunlaşmaktadır (Y1lmaz, 2004).

Alanyazında, sınıf içi etkinliklerin denetimi ve gözlemi konusunda farklı yaklaşımların ve tanımların olduğunu göstermektedir. Aydın'a (1986) göre okul formal bir örgüttür ve bu örgütteki etkinliklerin tümünün amaçlı ve ussal olması gerekir. $\mathrm{Bu}$, formal bir örgüt olmanın gereğidir. Sınıf denilen birimlerde kapalı kapılar ardında yapılanların, yapılması gerekenler olup olmadığı bilinmek durumundadır. Bunu bilmenin en akla uygun yollarından birisi de gözlemdir. $\mathrm{Bu}$, asla öğretmene güvensizlik olarak algılanmamalı, örgütsel bir zorunluluk olarak ele alınmalıdır.

Denetim sürecinden beklentilerle ilgili yapılan çalışmalarda, denetmenlerin öğretmenlerin mesleki gelişimine katkıda bulunmaları ve öğretimin denetimi gibi görevleri etkili olarak yerine getirilmeleri beklenmektedir (Yavuz, 2006; Ateş, 2007). Bergman (1998) okul müdürlerinin denetim uygulamalarını, öğretme ve öğrenme süreçlerine odaklanma olarak tanımlamaktadır. Bergman'a (1998) göre denetim sürecinin amacı yüksek nitelikte öğretim elde etmektir.

Çınar (2004) denetimi, bir okulda devam eden değerlendirme etkinliklerinin gözlenmesini kapsayan bir süreç olarak görmektedir. Çınar'a göre (2004) bazen, denetmenlerin kendileri etkinliklerin değerlendirilmesine doğrudan katılırlar.

Öğretmeni yeterli, kararlı, yetki ve sorumlulukları açık okul örgütleri ancak etkili sınıflarla kurulur ve yaşatılır. Öğretme ve öğrenme, okullardaki iki temel süreçtir. Okul müdürlerinin varlık nedeni, söz konusu süreçlerin iyi bir biçimde işleyebilmesini kolaylaştırmaktır. Okul müdürü, öğretmenlerin sahip oldukları potansiyeli ve becerileri tam olarak ortaya koyabilmelerini ve üst düzeyde performans gösterebilmelerini teşvik etmelidir (Şişman, 2002).

Eğitim denetiminde, öğrenme ve öğretme sürecinin geliştirilmesi için öğretmenlere yapılan yardımlar önemli görülmektedir. Öğretmenlerin potansiyellerini fark etmeleri ve etkili biçimde kullanabilmelerinde okul müdürleri önemli rol oynamaktadır. Sınıf içi performans, eğitim öğretimin en kritik noktasını oluşturmaktadır. Bu nedenle okul müdürünün sınıfa girmesi ve sınıfta neler olup bittiğini ayrıntılı olarak raporlayabilmesi son derece önemlidir. Yapılan sınıf içi gözlemler ve kullanılan yapılandırılmış teknikler, öğretmenin öğretimsel bilgi ve becerisinin değerlendirilmesi ve mesleksel gelişiminin sağlanması açısından önemli bir rol oynar.

Gözlem belirli bir amaç için bir nesne, olay veya ilişkinin, doğal koşullarda kendiliğinden olayın belirdiği sırada ya da bilinçli ve planlı olarak hazırlanan deney koşullarında sistematik olarak incelenmesidir (Özgüven, 2002). Gözlem bakmaktan farklı, planlı, sistemli bir eylemdir. Denetçi derste neleri nasıl gözlemleyeceğini planlamalı, bunları nasıl değerlendireceğini belirlemelidir. Aydın'a (2005) göre gözlem tesadüfî ve planlı gözlem olmak üzere ikiye ayrılmaktadır. Tesadüfî gözlemde gözlemcinin önceden organize ettiği ve 
amaçladığı bir durum yoktur. Organize edilmiş gözlemde ise kimin, nerede ve nasıl gözleneceği, gözlem yapılırken hangi formun kullanılacağı önceden belirlenmiştir.

Günlük yaşamda yapılan gözlemler informal gözlem; performansın değerlendirilebileceği çok yönlü, amaçlı, dinamik eylem süreçleri ise formal düzeyde adlandırılır. Bu çok yönlü süreç içinde kimin kimi, nerde, hangi kurallar çerçevesinde, hangi gözle aracıyla gözleneceği ve hedeflenen amacın ne olması gerektiği gibi pek çok unsur vardır (Aydın, 2005).

Gözlem araçlarının kullanımı davranış̧̧ı ve pozitivist, doğrudan yönlendirmeleri kabul ettiği için eleştirilmektedir (Eisner, 1998). Gözlem araçlarının kullanımı, doğrudan değerlendirme için sorun olabilir. Anlayış ve karşılıklı iletişime dayalı olarak kullanılan gözlem yöntemleri kişiler arası etkileşimleri cesaretlendirmek için kullanılabilir. Kullanımı kolay gözlem teknikleri, öğretmenin sınıf davranışları hakkında bilgi sahibi olmasını kolaylaştırır. $\mathrm{Bu}$ gözlem aracı ve tekniklerinin kullanımı ile gözlemciler ve bu gözlem sürecinde görev alanlar öğretmenlerle yakın olarak çalışmaları sayesinde öğretmenin anlatımını daha iyi düzeye çıkarır ve öğrencilerin başarılarını arttırırlar. Denetmen gözlem yöntemlerini kişiler arası etkileşimi cesaretlendirmek için kullanmalıdır (Sullivan ve Glanz, 2000).

Gözlem, doğrudan ve dolaylı olarak bilgi edinme biçimi olmakla beraber, değerlendirmenin vazgeçilmez bir parçasını oluşturmaktadır. Öğretmenin sınıf içi performansından ne beklendiği hakkında somut verilere ulaşabilmek, olgulara dayalı temel veriler elde edebilmek için yapılandırılmış teknikler gerekmektedir. Gözlemde, yapılandırılmış tekniklerle sınıfa girmek, öğretmenin öğretimsel performansının değerlendirilmesi ve öğretim sürecinin geliştirilmesi açısından önem taşımaktadır. Bu nedenle de bazı nitel ve nicel gözlem tekniklerinin açıklanması gerekmektedir.

\section{Öğretmen Sorularının Analizi}

Soru sorma, en önemli alı̧̧̧ırma-uygulama etkinliklerinden biridir. Soru sorma, aynı zamanda, etkileşimli bir sınıf ortamı, yaratarak dersin öğretmen merkezli olmaktan çıııp öğrenci merkezli olmasını sağlar. Etkili öğretmenler, öğrencilerin rahatça, çekinmeden yardım isteyebileceği açık, etkileşimli bir sınıf iklimi oluşturarak iyi sorularla dikkatli ve sürekli olarak öğrenci öğrenmelerini gözlemler (Özdemir ve Yalın, 1999).

Pek çok sınıfta öğretmenin en göze çarpan etkinlikleri, soru sorma biçimlerinin ve sıklığının gözlenmesidir. Öğretmen soruları, sınıftaki öğrenme açısından vazgeçilmez ve merkezi bir öneme sahiptir. Öğretmen sorularına ilişkin en temel gözlem yöntemi belirli bir ders süresince soruların sayısını ve niteliğini belirlemektir (Aydın, 2005).

Öğretmen sorularının analizinde kullanılan sistemlerden biri de Bloom'un taksonomisidir. Taksonomiye göre öğretmen soruları bilgi, kavrama, uygulama, analiz, sentez ve değerlendirmeden oluşan altı düzeyde ele alınır. Her bir soru bu düzeylere göre tutulacak bir çetelede işaretlenir. Tablo 1'de buna ilişkin bir örnek yer almaktadır (Sullivan ve Glanz, 2000). 
Tablo 1. Öğretmen Soruları Tablosu

\begin{tabular}{cccc}
\hline Soru Kategorisi & İşaret & Toplam & Yüzde \\
\hline Değerlendirme & $\mathrm{xx}$ & 2 & $\% 7$ \\
Sentez & & 1 & $\% 0$ \\
Analiz & $\mathrm{xx}$ & 1 & $\% 7$ \\
Uygulama & $\mathrm{x}$ & 1 & $\% 4$ \\
Kavrama & xxxxxxxx & 8 & $\% 30$ \\
Bilgi & xxxxxxxxxxxxxx & 11 & $\% 52$ \\
\hline
\end{tabular}

Dersin başlama saati:........

Toplam sorulan soru:

Dersin bitiş saati:

Sinif:

\section{Öğretmen Konuşma Davranışı Analizi}

Öğrencilerin en çok sevdikleri ve kendilerinden en fazla öğrendikleri öğretmenler, öğrenme içeriğinin kolayca anlaşılmasını sağlayacak bir öğretim yapan öğretmenlerdir. Öğretimin anlaşılırlığı, anlamlı düzenleme, temel noktaların belirlenmesi ve pekiştirilmesi, içeriğin bilinen ve çeşitli örneklerle desteklenmesi, iyi bir gözlem ve düzeltme işlemlerine bağlıdır (Özdemir ve Yalın, 1999). Öğretmenin öğrencilerle konuşma biçimi çok önemlidir. Bilgi verme, soru sorma, cevaplama, övme, yön gösterme, cevapları doğrulama davranışlarının sıklığı belirlenmelidir (Aydın, 2005).Tablo 2'de buna ilişkin bir örnek yer almaktadır

Tablo 2. Öğretmen Konuşma Davranışı Analizi

\begin{tabular}{|c|c|c|c|c|c|c|}
\hline & Bilgi verme & Soru sorma & Cevap verme & Övme & Yön gösterme & $\begin{array}{l}\text { Cevapları } \\
\text { doğrulama }\end{array}$ \\
\hline 1 & $\mathrm{X}$ & $\mathrm{x}$ & $\mathrm{x}$ & & & $\mathrm{x}$ \\
\hline 2 & $\mathrm{X}$ & $\mathrm{x}$ & $\mathrm{x}$ & & & $\mathrm{x}$ \\
\hline 3 & $\mathrm{X}$ & & & & & $\mathrm{x}$ \\
\hline 4 & $\mathrm{X}$ & & & & & \\
\hline 5 & $\mathrm{X}$ & & & & & \\
\hline 6 & $X$ & & & & & \\
\hline \multicolumn{7}{|l|}{7} \\
\hline 8 & & & & & & \\
\hline
\end{tabular}

Kaynak: (Sullivan, Glanz, 2000'den uyarlanmıştır.)

Dersin başlama saati

Sinif:

Dersin bitiş saati: 


\section{Sözel Olmayan Öğretmen Davranışlarının Analizi}

Öğretmenin sınıf içinde sergilediği davranışlar öğretim süreci açısından önemlidir. Sınıftaki öğrenme ve öğretme etkinliğinin temelinde etkili bir iletişim bulunmaktadır. Öğrenmenin istenilen düzeyde ve sağlıklı bir şekilde gerçekleşmesi öğretmen ve öğrenci arasında kurulacak iletişimin niteliğine bağlıdır. Sözel olmayan öğretmen davranışlarının denetmen tarafından gözlenmesi, öğretmenin farkında olmadan yaptığı birçok eylemin farkına varmasına ve sözel olmayan davranışları ile ilgili geribildirim almasına katkı sağlamaktadır. $\mathrm{Bu}$ yöntemle çoğu öğretmenin farkında olmadan kullandığı sözsüz iletişim davranışlarının niteliği ve sıklığı sayısal açıdan değerlendirilebilmektedir.

Sazak (2004) öğretmenliği, sözel ve sözsüz iletişimin tüm boyutlarının aynı sınıfta, bir ders saatinde yaşanan bir iletişim mesleği olarak ifade etmektedir. Sazak'a göre öğretmen sınıfta ses tonunu öğrencilerini etkileyici bir biçimde kullanmalı, göz göze geldiği öğrencilerine ne demek istediğini ifade edebilmelidir. Öğretmenler, öğrencilerin gösterdikleri istendik davranışları pekiştirme ya da ödüllendirme yöntemlerinde çeşitliliği esas almalıdırlar. Öğrencilere gülümseme, göz teması kurma, onlara fiziksel olarak yaklaşma, gerektiğinde onlarla birlikte gülme gibi öğretmen davranışları öğrencileri derse daha ilgili, daha katılımcı kılar (Özdemir ve Yalın, 1999). Öğretmen bedensel tepkilerinin, konuşulan konunun niteliğine uygun olmasına dikkat etmelidir. İletişim sürecinde, öğrenci ile kurulan göz teması da önemli bir etkendir. Gülümseme, başla onaylama, yürüyüş biçimi gibi birçok jest ve mimik iletişimi tamamlayıcı öğelerdir (Aydın, 2000). Tablo 3'de sözel olmayan öğretmen davranışlarının analizi verilmiştir.

Tablo 3. Sözel Olmayan Öğretmen Davranışlarının Analizi

\begin{tabular}{l}
\hline Sözsüz Yöntemler \\
\hline Öğrencilerin yanında durma \\
Öğrencilere doğru hareket etme \\
Öğrencilere dokunma \\
Göz kontağı \\
Gülümseme \\
Kollarını açma hareketi \\
Kaşlarını çatma \\
Sert bakma \\
Susmalarını işaret etme \\
Kollarını çapraz yapma
\end{tabular}

\section{Öğretmen Hareket Şemaları}


Bir öğretmenin sınıftaki hareketleri eğitimsel açıdan önemlidir. Öğrencilerle sınıf içinde kurulacak iletişim, sınıf mekânının en iyi şekilde kullanılmasına bağlıdır. Öğretim sürecinin canlı tutabilmesi, öğrencinin ilgi ve dikkatlerinin öğretmen üzerinde toplanabilmesi, öğretmenin sınıf mekânını kullanma durumu ile yakında ilgilidir. Aydın'a (2005) göre bu teknikte sınıfin bir krokisi çizilir. Öğretmenin sınıf içindeki hareketleri gözlenir ve resmedilir. Böylece öğretmenin sınıf mekânını kullanma ve öğrencilerle iletişim davranışları kolayca gözler önüne serilebilmektedir. Şekil 1'de öğretmen hareket şemasına ilişkin bir örnek verilmiştir.

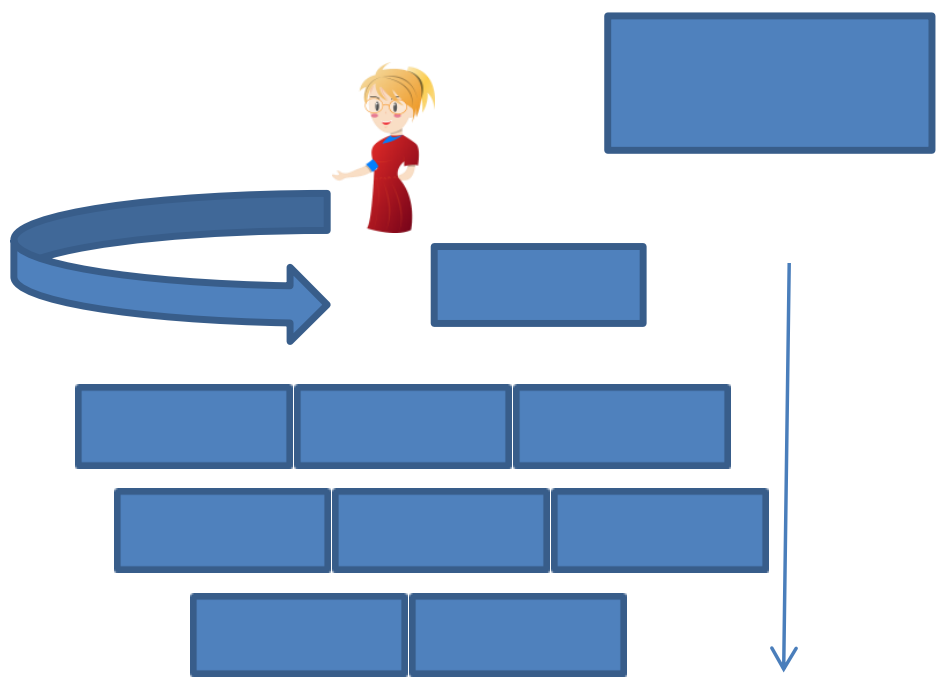

Şekil 1. Öğretmen Hareket Şemas1

\section{Sözel Akış Şemaları}

Denetmen ve ögretmenin birlikte karar verdikleri 30 dakikalık bir gözlem zamanı vardır. Öğretmenin öğrencilere ne kadar söz hakkı verdiğini ve öğrenciler arasındaki etkileşimi ortaya koyar. Şekil 2'de öğrencilerle olan etkileşimi ve her öğrenciye ne kadar söz hakk1 verdiği oklarla gösterilmektedir. 


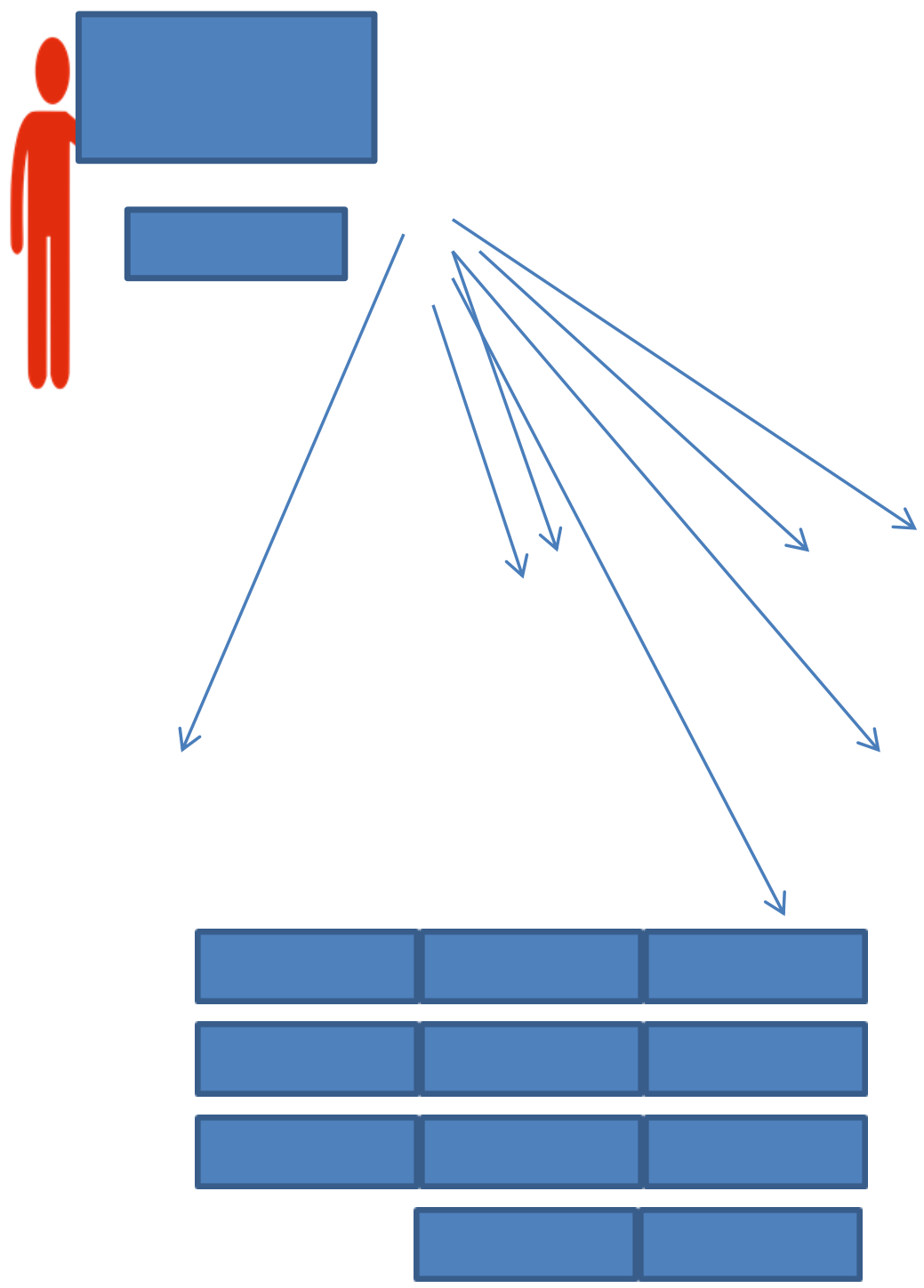

Şekil 2. Sözel Akış Şeması

Son yıllarda okul müdürlerinin rollerinde meydana gelen değișimler de okul müdürlerinin denetim etkinliklerine daha fazla önem verilmesi gerektiğini ortaya koymaktadır. $\mathrm{Bu}$ gelişmeler arasında en önemlisi belki de, okul müdürlerinin artık birer öğretim lideri olarak görülmesidir. Buna göre okul müdürlerinin birer öğretim lideri olarak, öğretmenlerin sınıf içindeki öğretim etkinliklerini denetlemeleri ve bu etkinlikleri geliştirici yönde etkinlikler düzenlemeleri gerekmektedir. Yani okul müdürlerinin odalarından çıkmaları, okullarında gezmeleri, sınıf içi etkinlikleri denetlemeleri, öğretmenler ile yakın bir ilişki kurmaları gerekmektedir. Tabi ki bütün bu etkinliklerin amacı eğitim öğretim etkinliklerinin 
geliştirilmesidir. Bütün bu gelişmeler okul müdürlerinin yerine getireceği denetim etkinliklerinin önemini artırmaktadır (Yılmaz, 2009).

Türkiye'de okul çağındaki nüfusun çokluğu yanında, eğitim kurumlarımızda sosyal, ekonomik, kültürel ve politik kaynaklı birçok sorun yaşanmaktadır. Bu sorunlar içinde okul yöneticiliği daha bir önem kazanmakta ve liderlik niteliklerine sahip okul yöneticilerine ihtiyaç duyulmaktadır. Okul yöneticilerinin etkili denetimi gerçekleştirebilmeleri için, denetim süreçleri, insan ilişkileri, konu alanı, insan kaynakları yönetimi, bilgi yönetimi gibi birçok alanlarda yetiştirilmeleri gerekir. Oysa ulaşılan birçok araştırma sonuçları okul müdürlerinin büyük çoğunluğunun insan kaynaklarının etkin yönetimi ve denetimi alanlarında yeterince bilgi ve beceriyle donanık olmadıklarını ortaya koymaktadır (Çağan, 1998; Dağl1, 2000; Güçlü, 1998; Özbaş, 2002; Taş, 2003). Ayrıca 20 Ağustos 2017 tarihinde yürürlüğe giren "Milli Eğitim Bakanlığı Teftiş Kurulu Yönetmeliği'nin müfettiş ve müfettiş yardımcılarının görev ve yetkileri başlıklı 34. Maddesinde "652 sayılı Kanun Hükmünde Kararnamenin 17'nci maddesinde belirtilen görevleri yapar" ifadesine yer verilmiştir. 14 Eylül 2011 tarihinde yürürlüğe giren ve Milli Eğitim Bakanlığının Teşkilat ve Görevlerini düzenleyen 652 sayılı Kanun Hükmünde Kararname'nin "Rehberlik ve Denetim Başkanlığı" başlıklı 17. Maddesinde, müfettişlerin, bakanlığın okul ve kurumlarına rehberlik etmeye ve bakanlık teşkilatı ile personelinin idari, mali ve hukuki işlemleri hakkında denetim, inceleme ve soruşturma yapmaya devam edecekleri ifade edilmiştir. Ancak ilgili maddede öğretmen teftişi görevinden söz edilmemiş̧ir. Bu durum okullarda öğretici olarak görev yapan öğretmenlerin eğitim ve öğretim etkinliklerinin gözlemlenmesi, incelenmesi ve değerlendirilmesi ile okul müdürlerinin eskiden beri var olan ders denetimi görevinin önemini daha da arttırmıştır. Bu nedenle bu araştırma, okul müdürlerinin gözlem teknikleri konusunda bilgilenmeleri ve bu teknikleri uygulama yeterliliklerinin arttırılmasına katk1 sağlayacaktır. Ayrıca okuldaki öğretim etkinliğinin daha nitelikli ve işlevsel hale gelmesini sağlayacak, böylece okulun esas amacı olan öğretimin niteliği artacak ve okulun beklenen amaçlarının gerçekleşmesine katkı sağlayacaktır. Bu araştırmada ilkokul müdürlerinin sınıf içi gözlem tekniklerini kullanarak, öğretmenlerin sınıf içi öğretim performanslarına yönelik saptamalarını değerlendirmeleri amaçlanmıştır.

\section{Yöntem}

$\mathrm{Bu}$ bölümde araştırmanın modeline, çalışma grubuna, verilerin toplanması ve analizine, araştırmacının rolüne, araştırmanın geçerlilik ve güvenirliliğine ilişkin bilgilere yer verilmiştir.

\subsection{Araştırma modeli}

$\mathrm{Bu}$ araştırmada tarama modeli kullanılmıştır. Araştırmada, ilkokullarda görev yapan okul müdürlerinin sınıf içi gözlem tekniklerini kullanarak, öğretmenlerin sınıf içi performanslarının belirlenmesi amaçlanmıştır. Araştırma, gözlem ve doküman analizi şeklindeki veri toplama yönteminin kullanıldığı, algıların ve olayların doğal ortamında gerçekçi ve bütüncül bir biçimde ortaya konulduğu için nitel araştırma yöntemidir. Araştırmada gözlem yoluyla bilgi toplama yöntemi kullanılarak, hem birinci elden, hem de ikinci elden gözlemler yapılmıştır. Gözlemle veri toplamada yazılı tasvirler kullanılmıştır. 


\section{2. Çalıșma Grubu}

Araştırmanın çalışma grubunu, Ankara'nın merkez ilçesi Çankaya'da bulunan ilkokullarda görev yapan ve bu çalışmada yer almayı gönüllü olarak kabul eden 10 okul müdürü ve bu okul müdürlerinin derslerine girdikleri 60 sınıf öğretmeni oluşturmuştur. Çalışma grubunun belirlenmesinde okul müdürlerinin en az beş yıllık yöneticilik deneyimlerinin olması ve görev yaptıkları okulda ders denetimleri ve gözlemleri konusunda deneyimlerinin olması ölçüt olarak alınmıştır. Çalışma grubuna alınan sınıf öğretmenlerinin belirlenmesinde, öğretmenlerin bu okulların üçüncü ve dördüncü sinıflarında görev yapmaları ve birinci sınıftan itibaren bu sınıfların sınıf öğretmenliğini yapmaları ölçüt olarak alınmıştır. Gözlem kapsamına alınan sınıf öğretmenlerinin sınıf içi gözlemleri fen bilimleri ve sosyal bilgiler dersleri ile sınırlı tutulmuştur.

Çalışma grubunu oluşturan okul müdürleri araştırmacı tarafindan seçilmiştir. Seçilen okul müdürlerine eğitim yönetimi ve denetimi alanında yüksek lisansını tamamlamış ve "sınıf içi gözlem teknikleri”" konusunda bilgi ve deneyime sahip ve aynı zamanda okul müdürü olarak görev yapan araştırmacı tarafindan yarıyıl tatilinde (1Şubat 2017) görev yaptığı okulun konferans salonunda 3 saat süren bir seminer verilmiştir. Seminere katılan okul müdürlerine örnek tablo 1, tablo 2,tablo 3 veri toplama formları ile şekil 1 ve şekil 2'deki örnekler dağıtılmıştır. Çalışma grubuna katılan okul müdürlerinin tamamı erkektir. Tablo 4'de çalışma grubunu oluşturan okul müdürlerinin yaş gruplarına göre dağılımını gösteren yüzdelik oranları ve frekansları yer almaktadır.

Tablo 4. Okul Müdürlerinin Yaş Gruplarına Göre Dağılımı

\begin{tabular}{llc}
\hline Okul müdürlerini yaşları & f & $\%$ \\
\hline $\mathbf{3 5 - 4 0}$ & 1 & 10 \\
$\mathbf{4 1 - 4 6}$ & 5 & 50 \\
$\mathbf{4 7 - 5 2}$ & 2 & 20 \\
$\mathbf{5 2 - 5 7}$ & 1 & 10 \\
$\mathbf{5 7}$ ve üstü & 1 & 10 \\
\hline
\end{tabular}

Tablo 4'de çalışma grubunu oluşturan okul müdürlerinin \%10'u 35-40, \%50'si 41-46, $\% 20$ 'si 47-52, \%10’u 52-57 ve \%10'u 57 ve üstü yaş grubundadır.

\subsection{Veri Toplama Araçları}

Veri toplama aracı olarak, bilimsel nitelik taşıyan doküman ve gözlem form örnekleri (sınıf içi gözlem teknikleri formları) seçilmiş, bu formlar çalışma grubuna dağıtılmıştır. Çalışma grubuna dağıtılan gözlem formları; öğretmen sorularının analizi, sözel akış şeması, hareket 
şeması, öğretmen konuşma davranışı analizi ve sözel olmayan öğretmen davranışları analizi formlarından oluşmaktadır.

\subsection{Verilerin Toplanması ve Analizi}

Araştırmada veriler gözlem yoluyla toplanmış, birinci ve ikinci elden gözlem teknikleri kullanılmıştır.

Toplanan 360 gözlem formundan 346'sı değerlendirilmiş, 24 gözlem formu hatalı bulunarak değerlendirmeye alınmamıştır. Toplam 54 öğretmen ve 1286 öğrencinin gözlem formları değerlendirilmiştir. Araştırmada elde edilen verilerin çözümlenmesinde frekans (f) ve yüzdelik (\%) değer kullanılmış ve yorumlama bu değerler üzerinde yapılmıştır.

\subsection{Araştırmacının Rolü}

$\mathrm{Bu}$ araştırma eğitim fakültesi mezunu, yedi yıllık öğretmenlik deneyimi ve 13 yıllık okul müdürlüğü deneyimi olan ve eğitim bilimleri fakültesi özel eğitim bölümüne doktora öğrencisi olarak devam eden araştırmacı tarafından gerçekleştirilmiştir. Araştırmacının yöneticilik deneyimi ve kendisi gibi okul müdürlüğü görevini yürüten yöneticilerle olan iletişimi araştırmanın rahat bir şekilde yürütülmesinde etkili olmuştur. Diğer taraftan araştırmacının yüksek lisansını eğitim yönetimi alanında yapmış olması, öğretmenlik ve yöneticilik deneyimini yüksek lisans derslerinde edindiği kuramsal bilgiler sentezlemesi araştırma sürecine ve sonucuna yansımış olması muhtemeldir. Araştırmacı, araştırma sürecince okul müdürleri ile sık sık iletişim kurmuş, sürece ilişkin bilgi almış ve okulları ziyaret etmiştir.

\subsection{Geçerlik ve Güvenirlik}

Bilimsel bir araştırmanın kalitesini onun geçerlik ve güvenirliği ortaya koyar. Geçerlik ve güvenirlik kavramları nitel araştırma geleneği içinde farklı anlamlar kazansa da nitel bir araştırmada geçerlik ve güvenirliği sağlamak için bazı önlemler alınır. (Yıldırım ve Şimşek, 2013: 289). Bu araştırmada geçerlik ve güvenirliği sağlamak için alınan önlemler şöyle siralanabilir:

$\checkmark$ Sınıf içi gözlem tekniklerinin uygulanmasına ilişkin okul müdürleri ile doğrudan görüşülmüş ve süreç içerisinde gerekli geri bildirimler verilmiştir.

$\checkmark$ Uygulama öncesi okul müdürleri görev yaptıkları okulların ikinci sınıf öğretmenlerinin derslerini gözlemleyerek pilot uygulamalar gerçekleştirmişler ve uygulama sonuçlarını araştırmacı ile paylaşmışlar ve olumlu geribildirimler vermişlerdir.

$\checkmark$ Uygulamalar sonrası okul müdürleri ile gözlem formları birlikte değerlendirilmiş, toplanan verilerin yeterliliği konusunda görüşbirliği sağlanmıştır.

$\checkmark$ "Verilerin toplanması ve analizi" başlığı altında da değinildiği üzere veri toplama süreci içinde genel hatlarıyla belirlenen sınıf içi gözlemler ve bu gözlemlerden elde edilen verilerin yeterliliği tespit edildikten sonra veri toplama işlemi 
sonlandırılmıştır. Böylece veri toplama süreçlerine uygun ve yeterli katılım sağlanmaya çalışılmıştır.

$\checkmark$ "Araştırmacı rolü" başlığı altında görüldüğü gibi araştırmacının bu araştırma içindeki rolü, konuya bakış açısı ve katılımcılarla etkileşimi ayrıntılı olarak ifade edilmiştir.

$\checkmark$ Toplanan gözlem formları eğitim yönetimi alanında yüksek lisansını tamamlamış ve nitel araştırma konusunda deneyimi olan iki okul müdürü tarafından da analiz edilmiş ve araştırmacının yapmış olduğu analizler ile karşılaştırılarak 14 form hatalı olduğu için değerlendirmeye alınmamıştır.

$\checkmark$ Değerlendirme kapsamına alınan formlardaki verilerin çözümlenmesinde de eğitim yönetimi alanında yüksek lisansını tamamlamış ve nitel araştırma konusunda deneyimi olan iki okul müdürü tarafından çözümleme yapılmış ve araştırmacının yapmış olduğu çözümlemelerle karşılaştırılarak frekansların doğruluğu teyit edilmiştir.

\section{Bulgular}

Araştırmadan elde edilen bulgular, tablolaştırılarak yorumlanmıştır.

Tablo 5. Öğretmenlerin Cinsiyetlere Göre Dağglımı

\begin{tabular}{lcc}
\hline Öğretmenlerin cinsiyetleri & f & $\%$ \\
\hline Kadın & 44 & 81 \\
Erkek & 10 & 19 \\
Toplam & 54 & 100 \\
\hline
\end{tabular}

Tablo 5'te sınıf öğretmenlerin \%81'inin kadın, \%19'unun ise erkek olduğu görülmektedir. Kadın öğretmenlerin sayısı erkek öğretmenlerin sayısının dört katından fazladır.

Tablo 6. Gözlem Yapılan Sınıfların Dağılımı

\begin{tabular}{lcc}
\hline Gözlem yapılan sinıflar & f & $\%$ \\
\hline 3.sinıf & 32 & 59 \\
4.sinif & 22 & 41 \\
Toplam & 54 & 100 \\
& & \\
\hline
\end{tabular}

Tablo 6'da toplam 54 sinıfta gözlem yapıldığı görülmektedir. Gözlem yapılan sınıfların, 32 'si ilkokul üçüncü sınıf ve 22'si ise ilkokul dördüncü sınıftır. En fazla gözlem yapılan sınıf üçüncü sinıflar olmuştur. 
Tablo 7. Gözlem Yapılan Öğrencilerin Dağılımı

\begin{tabular}{lcc}
\hline Öğrencilerin sınıfları & f & $\%$ \\
\hline 3. sinıf & 954 & 44 \\
4. sınıf & 546 & 36 \\
Toplam & 1500 & 100 \\
& & \\
\hline
\end{tabular}

Tablo 7 incelendiğinde öğrencilerin, \%44'ünün ilkokul üçüncü sınıf ve \%36'sının ise ilkokul dördüncü sınıf olduğu görülmektedir.

Aşağıda okul müdürlerinin kullanmış oldukları sınıf içi gözlem tekniklerine ve bu teknikler sonucunda öğretmenlerin sınıf içinde göstermiş oldukları öğretim performanslarına yer verilmiştir.

Tablo 8. Öğretmen Sorularının Analizi

\begin{tabular}{lll}
\hline Soru kategorisi & f & $\%$ \\
\hline Değerlendirme & 14 & 6 \\
Sentez & 16 & 7 \\
Analiz & 29 & 14 \\
Uygulama & 31 & 14 \\
Kavrama & 129 & 59 \\
TOPLAM & 219 & 100 \\
\hline
\end{tabular}

Tablo 8'de öğretmenlerin sınıf içinde sormuş oldukları soruların \%6'sının değerlendirme, $\% 7$ 'sinin sentez, \%14'ünün analiz, \%17'sinin uygulama ve \%59'unun kavrama düzeyinde soru olduğu görülmektedir.

Tablo 9. Öğretmen Sorularının Derslere Dağılımı

\begin{tabular}{l|l|l|l|l}
\hline Soru Kategorisi & \multicolumn{2}{l}{ Fen Bilimleri Dersi } & \multicolumn{2}{l}{ Sosyal Bilgiler } \\
\hline \multirow{3}{*}{ Değerlendirme } & f & $\%$ & f & $\%$ \\
\cline { 2 - 5 } Sentez & 3 & 4 & 11 & 8 \\
Analiz & 6 & 8 & 10 & 7 \\
Uygulama & 18 & 22 & 11 & 8 \\
Kavrama & 5 & 6 & 26 & 19 \\
TOPLAM & 49 & 60 & 80 & 58 \\
\hline
\end{tabular}


Tablo 9'da fen bilimleri dersinde sorulan soruların \% 4'ünün değerlendirme, \%8'inin sentez, $\% 22$ 'sinin analiz, \%6'sının uygulama ve \%49'unun ise kavrama düzeyinde; sosyal bilgiler dersinde sorulan soruların ise \% 8'inin değerlendirme, \% 7'sinin sentez, \% 8'inin analiz, \% 19 'unun uygulama ve \% 58'inin kavrama düzeyinde sorulan sorular olduğu görülmektedir.

Tablo 10. Öğretmen Konuşma Davranışlarının Analizi

\begin{tabular}{lll}
\hline & f & $\%$ \\
\hline Bilgi verme & 98 & 20 \\
Soru sorma & 152 & 31 \\
Cevap verme & 76 & 16 \\
Övme & 32 & 6 \\
Yön gösterme & 49 & 10 \\
Cevapları doğrulama & 86 & 17 \\
TOPLAM & 493 & 100 \\
\hline
\end{tabular}

Tablo 10'da öğretmenlerin \%20'sinin bilgi verme, \%31'inin soru sorma, \%16'sının cevap verme, \% 6'sının övme, \% 10'unun yön gösterme ve \% 17'sinin cevapları doğrulama konuşma davranışı sergiledikleri görülmektedir.

Tablo 11. Öğretmen Konuşma Davranışlarının Derslere Göre Dağılımı

\begin{tabular}{lllll} 
& \multicolumn{2}{l}{ Fen Bilimleri Dersi } & \multicolumn{2}{l}{ Sosyal Bilgiler Dersi } \\
\cline { 2 - 5 } Bilgi verme & f & $\%$ & f & $\%$ \\
Soru sorma & 23 & 15 & 45 & 20 \\
Cevap verme & 39 & 25 & 83 & 37 \\
Övme & 16 & 11 & 32 & 14 \\
Yön gösterme & 19 & 13 & 15 & 7 \\
Cevapları doğrulama & 24 & 16 & 24 & 11 \\
TOPLAM & 31 & 20 & 24 & 11 \\
\hline
\end{tabular}

Tablo 11'de fen bilimleri dersinde gözlem yapılan sınıf öğretmenlerinin \%15'inin bilgi verme, \% 25'inin soru sorma, \%11'inin cevap verme, \%13'ünün övme, \% 16'sinın yön gösterme ve $\% 20$ 'sinin cevapları doğrulama davranışı sergiledikleri görülmektedir. Sosyal 
Bilgiler dersi incelendiğinde ise öğretmenlerin \%20'sinin bilgi verme, \% 37'sinin soru sorma, \%14'ünün cevap verme, \%7'sinin övme, \% 11'inin yön gösterme ve \%11'inin cevapları doğrulama davranışı sergiledikleri görülmektedir. Tablo 11 incelendiğinde öğretmenlerin fen bilimleri dersinde göstermiş oldukları öğretmen konuşma davranışının cevap verme davranışı, sosyal bilgiler dersinde göstermiş oldukları öğretmen konuşma davranışının ise öğrencileri övme olduğu görülmektedir.

Tablo 12. Sözel Olmayan Öğretmen Davranışları Analizi

\begin{tabular}{lll}
\hline SÖZSÜZ YÖNTEMLER & f & $\%$ \\
\hline Öğrencilerin yanında durma & 110 & 19 \\
Öğrencilere doğru hareket etme & 132 & 23 \\
Öğrencilere dokunma & 43 & 8 \\
Göz kontağı kurma & 125 & 22 \\
Gülümseme & 58 & 10 \\
Kollarını açma hareketi & 26 & 5 \\
Kaşlarını çatma & 12 & 2 \\
Sert bakma & 30 & 5 \\
Susmalarını işaret etme & 36 & 6 \\
TOPLAM & 572 & 100 \\
\hline
\end{tabular}

Tablo 12'de sınıf öğretmenlerinin \%19'unun öğrencilerin yanında durduğu, \%23'ünün öğrencilere doğru hareket ettiği, \% 8'inin öğrencilere dokunduğu, \%22'sinin öğrencilerle göz kontağı kurduğu, \%10'unun gülümseme davranışı gösterdiği, \%5'inin kollarını açma hareketi yaptığ, \% 2 'sinin kaşlarını çattı̆̆ 1 \% 5'inin öğrencilere sert baktığı ve \% 6'sının ise öğrenciler susmalarını işaret ettiği görülmektedir. Öğretmenlerin göstermiş oldukları en fazla sözel olmayan öğretmen davranışının öğrencilere doğru hareket etme davranışı, en az göstermiş oldukları davranış ise kaşlarını çatma davranışı olduğu görülmektedir.

Tablo 13. Sözel Olmayan Öğretmen Davranışlarının Cinsiyetlere Göre Analizi

\begin{tabular}{lcccc}
\hline & \multicolumn{2}{c}{ Kadın } & \multicolumn{3}{c}{ Erkek } \\
\cline { 2 - 5 } SÖZSÜZ YÖNTEMLER & $\mathrm{f}$ & $\%$ & $\mathrm{f}$ & $\%$ \\
& & & 34 & 14 \\
Öğrencilerin yanında durma & 76 & 22 & 65 & 28 \\
Öğrencilere doğru hareket etme & 67 & 20 & 14 & 6 \\
Öğrencilere dokunma & 29 & 9 & & \\
\hline
\end{tabular}




\begin{tabular}{lcccc}
\hline Göz kontağı kurma & 55 & 16 & 70 & 30 \\
Gülümseme & 40 & 12 & 18 & 8 \\
Kollarını açma hareketi & 19 & 6 & 7 & 3 \\
Kaşlarını çatma & 8 & 2 & 4 & 2 \\
Sert bakma & 20 & 6 & 10 & 4 \\
Susmalarını işaret etme & 25 & 7 & 11 & 5 \\
TOPLAM & 339 & 100 & 233 & 100 \\
\hline
\end{tabular}

Tablo 13 incelendiğinde gözlem yapılan kadın sınıf öğretmenlerinin \%22'sinin öğrencilerin yanında durduğu, \%20'sinin öğrencilere doğru hareket ettiği, \% 9'unun öğrencilere dokunduğu, \%16'sının öğrencilerle göz kontağı kurduğu, \%12'sinin gülümseme davranış1 gösterdiği, \%6'sının kollarını açma hareketi yaptığı, \%2'sinin kaşlarını çattı̆̆ı, \%'6'sının öğrencilere sert baktığı ve \% 7'sinin ise öğrencilere susmalarını işaret ettiği görülmektedir. Erkek öğretmenlerin ise \%14'ünün öğrencilerin yanında durduğu, \%28'sinin öğrencilere doğru hareket ettiği, \% 6'sının öğrencilere dokunduğu, \%30'unun öğrencilerle göz kontağı kurduğu, \%8'inin gülümseme davranışı gösterdiği, \%3'ünün kollarını açma hareketi yaptı̆̆ı, \%2'sinin kaşlarını çattığı, \%'4' 'ünün öğrencilere sert baktığı ve \% 5'inin ise öğrencilere susmalarını işaret ettiği görülmektedir. Kadın öğretmenlerin en fazla sergiledikleri sözel olmayan öğretmen davranışı öğrencilerin yanında durma davranışı iken, erkek öğretmenlerin en fazla sergiledikleri sözel olmayan öğretmen davranışı öğrencilerle göz kontağı kurmadır. Kaşlarını çatma davranışı ise kadın ve erkek öğretmenlerin en az sergiledikleri sözel olmayan öğretmen davranışları olmuştur.

Tablo 14. Öğretmen Hareket Şeması Analizi

\begin{tabular}{lcc}
\hline \multicolumn{1}{c}{ Kullanian alan } & f & $\%$ \\
\hline Masaya hareket & 78 & 14 \\
Tahtaya hareket & 96 & 17 \\
Kapıya hareket & 21 & 4 \\
Ön siralar & 146 & 25 \\
Orta siralar & 154 & 27 \\
Arka siralar & 71 & 13 \\
TOPLAM & 566 & 100 \\
\hline
\end{tabular}

Tablo 14'de gözlem yapılan sınıf öğretmenlerinin \%14'ünün masaya, \%17'sinin tahtaya, \%4'ünün ise kapıya doğru hareket ettiği görülmektedir. Öğretmenlerin \%25'i ön sıralarda hareket ederken, \%27'si orta sıralarda ve \%13'ü ise arka sıralarda hareket etmişlerdir.

Tablo 15. Sözel Akış Şeması Analizi

\begin{tabular}{lcc}
\hline Öğrenci Yerleșim Düzeni & f & $\%$ \\
\hline Ön sırada olup söz verilenler & 108 & 45 \\
\hline
\end{tabular}




\begin{tabular}{lcc}
\hline Orta sirada olup söz verilenler & 76 & 32 \\
Arka sırada olup söz verilenler & 54 & 23 \\
TOPLAM & 238 & 100 \\
\hline
\end{tabular}

Tablo 15'de sinıf öğretmenlerinin \%45'inin ön sırada oturan öğrencilere söz verdikleri, $\% 32$ 'sinin orta sırada oturan öğrencilere söz verdikleri ve \%23'ünün ise arka sırada oturan öğrencilere söz verdikleri görülmektedir.

\section{Sonuç, Tartışma ve Öneriler}

$\mathrm{Bu}$ araştırmadan elde edilen bulgular ilkokul üçüncü ve dördüncü sınıflarda derse giren sınıf öğretmenlerinin çoğunun kavrama düzeyinde sorular sorduklarını, sentez ve uygulama düzeyinde sorulan soruların ise sınırlı olduğunu ortaya koymuştur. Araştırmanın bulguları sınıf öğretmenlerinin fen bilimleri ve sosyal bilgiler derslerinde en çok kavrama düzeyinde sorular sorduğunu göstermiştir. Araştırma bulguları ayrıca sınıf öğretmenlerinin fen bilimleri dersinde en az değerlendirme düzeyinde sorular sorduklarını, sosyal bilgiler dersinde ise en az uygulama düzeyinde sorular sorduklarını ortaya koymuştur. Yapılan araştırmalar, öğretmenlerin soru sorma özelliklerini, öğretim birikimlerinin özü olarak gördüklerini ortaya koymuştur. Yaklaşık bir yüzyıl önce R. Stevens, bir lise öğretmeninin bir öğretim günü içinde neredeyse 400 soru sorduğunu keşfetmiştir. S.J.Doneue ise her bir derste bir öğretmenin 6 ile 16 arası soru sorduğunu, soru sayısının öğretim düzeyi ve öğretilen konuya bağlı olarak değiştiğini ortaya koymuştur (Aydın, 2005). Dolayısıyla fen bilimleri derslerinde analiz, sentez ve değerlendirme sorularına daha fazla yer verilmeli, sosyal bilgiler derslerinde ise uygulama sorularının sorulma düzeyleri arttırılmalıdır.

$\mathrm{Bu}$ araştırmadan elde edilen bulgular öğretmenlerin çoğunluğunun soru sorma davranış1 gösterdiğini ortaya koymuştur. Araştırma bulguları ayrıca, en az gösterilen öğretmen konuşma davranışının övme davranışı olduğunu göstermiştir. Araştırmanın bu bulgusu oldukça dikkat çekicidir. Övme davranışının en az gösterilen öğretmen davranışı olması düşündürücüdür. Hâlbuki alanyazında derse katılan, soruları doğru cevaplayan, olumlu ve örnek davranışlar sergileyen öğrencilerin, öğretmenler tarafından mutlaka övülmesi gerektiği ifade edilmektedir. Aydın'a (2005) göre övme ve eleştiri, öğretmenlerin öğrencilere verdiği geri bildirimin en fazla gözlenen biçimlerindendir. Samimi övgüler, öğrencilerin öğrenmesini ve öğrenme sırasında ortaya çıkabilecek engellerle mücadelelerinde onlara destek sağlayacaktır. Olumsuz eleştiriler ise bunun tam tersine yol açabilecektir. Öğreneni destekleyici sözlerin söylenmesi, problemlerin çözümlerine yönelik açıklamaların yapılması öğretimi daha etkili hale getirecektir.

Hyman (1986) öğretmenlerin sözel davranışları içinde yer alan ve gözlenmesi gereken en önemli alanlardan birinin öğretmenlerin öğrencileri yönlendirme biçimi olduğunu ifade etmektedir. Hyman'a (1986) göre öğretmen yönergeleri, öğretmenin öğrencilerin fiziksel ve bilişsel anlamda bir şeyler yapmalarını istediği durumlarda ortaya çıkmaktadır. Oysaki bu araştırmanın bulguları öğretmenlerin yönlendirme davranışlarının en az sergilenen öğretmen davranışlarından biri olduğunu göstermiştir. Araştırmanın bu bulgusu öğretmenlerin sınıf içindeki yön gösterme davranışlarının arttırılması gerektiğini ortaya koymaktadır. Yön gösterme davranışının arttırılması öğrencilerin desteklendiklerini ve benimsendiklerini hissetmelerini sağlayacak ve öğrencileri öğrenmeye daha fazla güdüleyecektir. 
Araştırma bulguları öğretmenlerin çoğunluğunun öğrencilere doğru hareket etme davranış1 gösterdiğini, kaşlarını çatma, sert bakma ve öğrencilere dokunma davranışlarının en az sergilenen sözel olmayan ögretmen davranışları olduğunu orta koymuştur. Bu araştırmanın bulguları ayrıca bayan öğretmenlerin en fazla öğrencilerin yanında durma davranışını sergilediklerini, erkek öğretmenlerin ise en fazla öğrencilerle göz kontağı kurma davranış1 sergilediklerini göstermiştir. Bayan öğretmenler erkek öğretmenlere göre daha fazla gülümseme davranışları sergilese de her iki öğretmen grubunda da gülümseme davranışı sınırlı kalmıştır. Oysaki öğretmenlerin, öğrencilere daha fazla gülümsemeleri hem meslek coşkularının görülmesini sağlayacak hem de öğrencilerine karşı olan sevgi ve samimiyetlerini ortaya koyarak onlara değer verdiğini ispatlayacaktır. Erkek öğretmenlerin öğrencilerle göz kurma davranışlarının fazla olmasının önemli olduğu söylenebilir. Öğretmenlerin ders işleme sürecinde öğrencilerle daha fazla göz kontağı kurmaları sınıf içi iletişimde önemli bir yer tutmakta, öğrenme ve öğretme etkililiğinin temelini oluşturmaktadır. Öğretmenlerin sözel olmayan davranışlarının öğrenciler üzerinde yarattığı etkinin önemi düşünüldüğünde sözel olmayan öğretmen davranışları analizinin öğretmenlerin farkında olmadan sergilemiş oldukları sözel olmayan davranışların niteliği ve sıklığının öğretmenin göz önüne serilebilmesi açısından önemli olduğu söylenebilir.

$\mathrm{Bu}$ araştırmanın bulguları sınıf öğretmenlerinin çoğunun orta ve ön sıralarda hareket ettiklerini, arka sıraların ise çok az kullanıldığını ortaya koymuştur. Araştırma bulguları ayrıca öğretmenlerin ön sıralarda oturan öğrencilere daha çok söz verdiklerini, arka sıralarda oturan öğrencilere ise daha az söz verdiklerini göstermiş̧tir. Acheson ve Gall'a (2003) göre öğrencinin öğrenme durumu, dikkat düzeyi ve güdülenmesi ile yakın ilişkilidir. Eğer öğretmen öğrencilere konuşma firsatları yaratır ve etkileşimini doğrudan öğrenci üzerinde odaklarsa, öğrenci bundan etkilenerek daha iyi öğrenecektir. Sözel etkileşim, öğrencilerin öğrendiklerinin anlamını keşfetmelerinin ve yeni bilgileri uygulayabilmelerinin en önemli araçlarından biridir. Öğretmenler, sınıfın sadece ön ve orta alanlarını değil, tamamını kullanmaya özen göstermelidirler. Etkili öğretimi gerçekleştirmek, öğrencilerin ilgi ve dikkatlerini sağlamak ve bunu ders boyunca sürdürebilmek öğretmenlerin sinıf içi hareketlerine bağlıdır. Sınıfın önünden nadiren ayrılan öğretmenlerin, öğrencilerin ilgi ve dikkatlerini sağlayamadıkları ifade edilmektedir. Sınıfta gerçekleştirilen her türlü etkinliğin belirli bir iletişim sistematiği içinde gerçekleştiği düşünüldügünde, sınıfta sağliklı ve etkin bir iletişimi gerçekleştirmenin temel yolu öğretmenin mümkün olduğunca her öğrenciye yakın bir fiziksel konumda bulunmasıdır. Öğrenmenin istenilen düzeyde gerçekleşmesi sınıf içinde kurulacak sağlıklı iletişime bağlıdır. Sınıf mekânını iyi kullanan bir öğretmenin, öğrencilerle daha iyi iletişim kuracağı, sınıftaki istenmeyen davranışları azaltacağı unutulmamalıdır. 


\section{KAYNAKÇA}

ACHESON, Keith A.,GALL, M. D. (1987). Techniques in the clinicalsüpervision of teachers. New York: Longman.

ATEŞ, F. (2007). Illköğretim okulu ögretmenlerinin denetim sürecinden beklentileri ve bunların gerçekleşme düzeyleri. (Yayınlanmamış Yüksek Lisans Tezi).Inönü Üniversitesi, Malatya.

AYDIN, M. (1986). Çă̆daş eğitim denetimi. Ankara: İm Yayınları.

AYDIN, A. (2000). Sinıf yönetimi. Ankara: Anı yayıncıl1k

AYDIN, İ. (2005). Öğretimde denetim. Ankara: Pegem.

BERGMAN, A.B. (1998). Elementary School Principal: With Reproducible Forms, Checklists, and Letters.San Francisco:Jossey-Bass

ÇAĞAN, V. (1998). Illköğretim okulu öğretmenlerinin okul müdürlerinin liderlik ve denetim becerilerine ilişkin algı ve beklentileri. (Yayınlanmamış Yüksek Lisans Tezi). Dokuz Eylül Üniversitesi, İzmir.

ÇINAR, İ. (2004). Eğitimde denetim ve değerlendirme. http//egitisim.inonu.edu.tr/ ikram_denetim.htm.

DAĞLI, A. (2000). İlköğretim öğretmenlerinin algılarına göre ilköğretim müdürlerinin etkili müdürlük davranışları. Kuram ve Uygulamada Eğitim Yönetimi, 23, 431-442.

GÜÇLÜ, N. (1998). Okul müdürlerinin sosyal beceri düzeylerinin belirlenmesi üzerine bir araştırma. VII. Ulusal Ĕgitim Bilimleri Kongresi, Cilt.2, 39-752.

EISNER, E. W. (1998). The enlightenedeye. qualitative inguiry and - the enhancement of educational practice. Prentice Hall, İnc.

HYMAN, R. T. (1986). School administrator's faculty supervisionhandbook. Prentice-Hall, EnglewoodCliffs, N.J.

Özbaş, M. (2002). İlköğretim okulu müdürlerinin sınıf içi etkinliklerin denetiminde yapmalarl gereken ve yapmakta olduklarl işler konusunda müdür ve ögrretmen görüşleri. (Yayınlanmamış Yüksek Lisans Tezi). Hacettepe Üniversitesi, Ankara.

Özdemir, S., Yalın, İ. (1999). Öğretmenlik mesleğine giriş. Ankara: Nobel Yayınc1lık

ÖZGÜVEN, İ. E. (2002). Çăgdaş eğitimde psikolojik danışma ve rehberlik. Ankara: Pdrem Yayınları

SAZAK, S. (2004). Yeni Eğitim. Üç Aylık Süreli Eğitimci Dergisi. Sayı 6, Ankara.

SULLIVAN, S., GLANZ, J. (2000). Supervision that improves teaching strategies and techniques. Sage Publication.

ŞiŞMAN, M. (2002). Öğretim liderliği. Ankara: Pegem Yayıncılık

TAŞ, A. (2003). İlköğretim okul yöneticilerinin öğretim liderliği rollerini gerçekleştirme durumları. Eğitim Araştırmaları, 11,166-176.

YAVUZ, M. (2006). İlköğretim okul müdürlerinden beklenen roller ve karş1lanma düzeyleri. Selçuk Üniversitesi Sosyal Bilimler Enstitüsü Dergisi, 16, 657-670. 
YILMAZ, K. (2004). Sanatsal denetim. Kuram ve uygulamada eğitim yönetimi dergisi, say1, 38, Ankara.

YILMAZ, K. (2009). Okul müdürlerinin denetim görevi. İnönü Üniversitesi Journal of the faculty of education, 10,1.

YILDIRIM, A. ve ŞİMŞEK, H. (2013). Sosyal bilimlerde nitel araştırma yöntemleri Ankara: Seçkin Yayınevi. 